\title{
Adrian Chircu-Buftea, Précis de morphologie romane, Casa Cărții de Știință, Cluj-Napoca, 2011, 184 p.
}

\author{
Anda Bratu* \\ Faculty of Letters, "Babeș-Bolyai" University, Str. Horea 31, 400202 Cluj-Napoca, Romania
}

Written in the French language, this volume brings an important contribution to the study of Romance languages, which lately have not aroused so much the interest of Romanian linguists. In the foreword, the author confesses that: "le manque d'ouvrages de morphologie romane, surtout en Roumanie, nous a déterminé à concevoir un livre synthétique facile à consulter et source de nombreux enseignements linguistiques" (p. 5).

This work has an illustrative character and offers to those interested information about the evolution of the morphological system, from the Latin language, towards Romance languages. It consists of ten synthetic chapters which describe the so-called "parties du discours": noun, adjective, article, pronoun, numeral, verb, adverb, preposition, conjunction and interjection. The length of these chapters varies depending on the distinctions that occur when approaching a part of discourse. For example, the ones dedicated to the pronoun or the verb are the most extensive ones (and this is due to the variety of types of pronoun: personal, reflexive, indefinite, etc. or due to different aspects concerning verbs: conjugations, moods and tenses, voices, etc.). In contrast with these ones, the chapters about interjections and conjunctions are less extensive. In the volume's structure, there is also included a very rich bibliography which shows an up to date reading of the literature and an index of authors.

Being specialized in Romance languages but also in Romanian language, the author analyses seven of these: Romanian, French, Italian, Spanish, Portuguese, Catalan, Provençal, and sometimes also refers to Sardinian, Dalmatian and Rhetoroman. There must be also stated that sometimes he uses examples not just from the modern aspect of these Romance languages but also from the ancient one (e.g., the article in Spanish "anc. esp. masc. (sing.) el (elo, lo) / pl. los (elos) vs. esp. mod. masc. (sing.) el (lo) / pl. los") (p. 39). The declared aim of the ten chapters is to illustrate the main changes that had taken place in the approached discourse categories in all the seven Romance languages and, additionally, the specificity of each of them.

The approach of this book is based on a great variety of examples taken from all the analysed Romance languages, examples about which the author claims that are generally constructed. Some of them are presented within a context "port. Não manifestou nenhuma surpresa. [Il ne manifeste aucune surprise.]" (p. 78), the others are presented independently "it. pochino 'un tout petit peu"' (p. 134), but, for the both, a translation in French is provided.

Structurally, each chapter contains a definition of the approached part of discourse and an analysis of its particular grammatical categories, in evolving from Latin, towards Romance languages. These categories are illustrated using different and well picked examples, the aim of which is, as mentioned above, highlighting the specificity or, sometimes, the resemblance between the discussed languages.

The first of the ten synthetic chapters, called "Le nom", discusses about the noun and its particular grammatical categories: gender, number, case. In what concerns the gender, Romanian language is the only one, from the family of Romance languages, which still has the neuter gender, inherited from Latin (p. 10). The second grammatical category, the number, is conveyed in Romance languages through plural inflections of vowel type (the case of Romanian and Italian) or consonantal type for the other Romance languages (p. 15). Regarding the case, the author underlines that in Latin there were six cases: Nominative, Accusative, Genitive, Dative, Ablative and Vocative but, in the evolution towards Romance languages, these had reduced first to five and then

*Email address: andabratu@yahoo.com. 
to three (in Vulgar Latin) and in the Romance languages it arrived to two cases: "cas sujet et cas régime" (p. 17-18). Romanian language represents the exception because it kept from Latin three case forms.

In the second part of the book, dedicated to adjectives, it is insisted upon the grammatical category of comparison, since it is through it "l'adjectiv se différencie des autres parties de discourse variables" (p. 24), in spite of the fact that in Romance languages there are few adjectives that do not posses grades of comparison "it. eterno, rom. perfect" (p. 34). The comparison has three grades: positive, comparative, and superlative. The author considers that the positive should not be counted as a grade of comparison, since it does not express any idea of comparison, but represents "une catégorie comparative neutre" (p. 24). In Classical Latin, the comparative was expressed synthetically with the help of some suffixes (-ior, -ius) (p. 26), but in Vulgar Latin analytical forms started to be used and Romance languages preserved the last ones "fr. - infériorité: Michel est moins grand que Georges" or "cat. superiorité: És més car que l'e-mail" (p. 27-28). The preference of Romance languages for analytical forms instead of synthetic ones (specific for Classical Latin) can be encountered also in the case of superlative "port. superlatif relatif de supériorité: Este aluno é o mais estudioso do Colégio" (p. 32).

The chapter "L'article" discusses about three types of articles: definite, indefinite and partitive. Latin language did not posses an article (p. 36), this began to appear in Vulgar Latin, and the forms from the Romance languages of today are descendents of the Latin demonstratives ipse, but, especially, ille (p. 37). The great majority of Romance languages prefers the analytical definite articulation, only in Romanian it is synthetic (p. 38). Generally, the indefinite articles from Romance languages come from the Latin numerals: unus, una, unum, but also from other parts of discourse (p. 41). From all the Romance languages, French uses most frequently partitive articles "fr. $d u$, de la, des" (p. 42). In addition to the three types, the linguist brings into question two more, specific to Romanian "larticle possessif ou génitif" and "l'article démonstratif ou adjectif" (p. 43).

"Le pronom", one of the two larger chapters, deals with 9 types of pronoun: personal, of politeness, reflexive, demonstrative, indefinite, of re- inforcement, possessive, negative and all together, relative, interrogative, and "exclamatif". From all of these, the forms of the pronoun of politeness from Romanian have their source in the Latin nouns "dominus et domina" (p. 49), whereas the other Romance languages express politeness through forms that belong to different types of pronouns or even different parts of discourse (p. 50). The pronoun of reinforcement is specific to Romanian and comes from the demonstrative $\mathrm{ipse}$ to which the reflexive pronoun is added (p. 60). From all the types of pronoun, the possessive one proves to be the most conservative in relation to Latin (p.61). The relative, interrogative and "exclamatifs" pronouns are treated together due to the formal resemblances between them (p. 67), and the last two are specific to spoken language (p. 72). The most frequently used relative pronoun in the oriental part of the Roman Empire was qualem and its descendants can be found today in Romance languages. Among the interrogative pronouns the most spread was quis (p. 72).

The fifth chapter, the numeral, describes in detail the two major types of numerals: cardinal and ordinal which characterize all Romance languages but also their source, Latin (p. 79). Regarding the cardinal ones, the authors again observes several new aspects specific to Romanian, among which we bring into discussion only one referring to the numerals from 11 to 19 . These are formed from elements of Latin origin but they represent structural calques after a Slavic model (p. 83). All the subtypes of cardinal numerals (collective, fractional, multiplicative, distributive and adverbial) are illustrated through a great variety of examples from all Romance languages (p. 86-87). The ordinal numerals are not insisted upon since are formed from the cardinal ones but, again, the Romanian is individualized through the analytical structure of it (rom. al doilea, a doua vs. it. secondo, cat. segon, port. segundo) (p. 85-86).

Almost as vast as the one dedicated to the pronoun, the chapter about the verb contains the analysis of: conjugations, number and person, personal and impersonal moods, and voices. The Latin verbs were separated into 4 conjugations but over time several crossings from one conjugation to another have taken place (p.91-92), and in the end it came to 3 conjugations in the majority of Romance languages and 4 conjugations in Romanian (p. 93). In the bulk of Romance languages, the distinction sin- 
gular/plural is pertinent; the exception is French which has homonymic forms (p. 94). In the discussion regarding the verbal moods and tenses, we insist only upon: the inexistence of conditional in Latin (p. 103); the "prezumtiv" mood specific to Romanian (p. 95); the existence of imperfect and past perfect subjunctive in the other Romance languages and their absence from Romanian (p. 107); the existence of two terms for imperative (in Romanian and Spanish), in comparison to the other Romance languages which have up to five terms (p. 110); the existence of supine mood only in Romanian (p. 113). In the Romance languages there are generally three voices (active, passive and reflexive), but French is an exception since it owns a fourth type, "factitive" (p. 119).

In the chapter dealing with the adverb, the linguist highlights the fact that, in Romance languages, there is a tendency of replacing the synthetical forms with the analytical ones formed "à l'aide des prépositions ou de particules qui entrent généralement en relation avec un adverbe pour le «soutenir», autant de points de vue phonétique que sémantique" (p. 124). In the majority of Romance languages the affix -mente (originating from a noun) helps the formation of adverbs, but Romanian prefers the ad- verbial suffix -eşte (p. 125-126). The author concludes that, in spite of the heterogeneity of this part of discourse (resulted from the diversity of forms), comparing Romance languages proves the contrary, meaning a certain unity (p. 134).

The last three chapters are not so vast and the first one of them is dedicated to prepositions which originate from Latin. The linguist makes an inventory of these prepositions both for Latin and Romance languages, and for the ones from Romanian and Latin, he also mentions the case regime (p. 138-142). The same descriptive character may be observed also in the chapter about conjunctions which contains a list of them for each Romance language, to which Latin is added. Regarding the interjections, there is a classification of them not dependent on the language they belong to, but dependent on their semantics (expressing pain, calling, joy, outrage, admiration, etc.) (p. 152-154).

Even though it has a synthetic character and, consequently, does not exhaustively treat all the aspects (as the author himself admits in the foreword), the book approaches the most representative ones and these are sufficient for shaping the complete portrait of the Romance morphological system. 